\title{
The Awareness of and Input into Cultural Heritage Preservation by Urban Planners and Other Municipal Actors in Light of Climate Change
}

\author{
Paul Carroll * and Eeva Aarrevaara
}

Citation: Carroll, P.; Aarrevaara, E. The Awareness of and Input into Cultural Heritage Preservation by Urban Planners and Other Municipal Actors in Light of Climate Change. Atmosphere 2021, 12, 726. https:// doi.org/10.3390/atmos12060726

Academic Editor: Yasemin D. Aktas

Received: 15 March 2021

Accepted: 28 May 2021

Published: 6 June 2021

Publisher's Note: MDPI stays neutral with regard to jurisdictional claims in published maps and institutional affiliations.

Copyright: (C) 2021 by the authors. Licensee MDPI, Basel, Switzerland. This article is an open access article distributed under the terms and conditions of the Creative Commons Attribution (CC BY) license (https:// creativecommons.org/licenses/by/ $4.0 /)$.
Faculty of Technology, LAB University of Applied Sciences, Mukkulankatu 19, 15210 Lahti, Finland; eeva.aarrevaara@lab.fi

* Correspondence: paul.carroll@lab.fi; Tel.: +358-414645092

\begin{abstract}
Future climate conditions need to be considered in planning for urban areas. As well as considering how new structures would best endure in the future, it is important to take into account factors that contribute to the degradation of cultural heritage buildings in the urban setting. Climate change can cause an increase in structural degradation. In this paper, a review of both what these factors are and how they are addressed by urban planners is presented. A series of inquiries into the topic was carried out on town planning personnel and those involved in cultural heritage preservation in several towns and cities in Finland and in a small number of other European countries. The target group members were asked about observed climate change impacts on cultural heritage, about present steps being taken to protect urban cultural heritage, and also their views were obtained on how climate change impacts will be emphasised in the future in this regard. The results of the inquiry demonstrate that climate change is still considered only in a limited way in urban planning, and more interaction between different bodies, both planning and heritage authorities, as well as current research on climate change impacts, is needed in the field.
\end{abstract}

Keywords: cultural heritage; urban planning; climate change

\section{Introduction}

Urban planning involves catering for the needs of urban dwellers and those using the urban area in the future. It needs to allow for growth in population, for increasing traffic and for any other future conditions that are likely to arise. Town and city planners need knowledge from a range of fields, including future foresight skills, in addition to the required knowledge of urban sustainability, engineering and architecture. Urban planning needs to also consider the existing environment and heritage and the impacts of the possible changes due to urbanisation and other phenomena like climate change. In the case of cultural heritage buildings and areas, it is usually a matter of this being defined in advance by authorities such as museum and antiquities departments, thereby communicating to planners the necessity to incorporate their preservation as part of the urban plans. Others involved in cultural heritage preservation need local knowledge regarding the relative value of different sites, comparative knowledge of threats or damage already incurred to similar structures elsewhere, among other skills. The community's cultural values are also found to be of importance for the future preservation opportunities, which involve not only authorities, but community members and stakeholders with the assistance of participatory planning [1].

Cultural heritage in the broader sense consists of archaeological remains, cultural sites and environments together with the infrastructure they involve, including building exteriors and interiors. There is also an ethnographical distinction between such material cultural heritage and that of the immaterial type (culture, customs, ceremonies, storytelling, music, etc.). This paper deals with tangible, immovable cultural heritage [2]. 
National legislation gives instructions for implementing the national planning system, usually incorporating different levels of more general or detailed plans in urban areas. It has been noticed that several European countries launched an official planning system linked with the preservation of cultural heritage after the second World war [3]. From the perspective of urban planning, it is essential to comprehend that preservation needs to be considered from the viewpoint of larger areas, and not only separate buildings. The concept of preservation is dynamic and changes over time. The UNESCO convention [2] recognised monuments, groups of buildings, and sites as different forms of cultural heritage. However, Janssen et al. [3] argue that there is still a gap remaining between the integration of planning and the preservation of historical built environment. In this article, we explore this argument in the context of authorities working in both fields and the special focus is on the climate change impact in cultural heritage and its consideration in urban planning. It is not a coincidence that more attention was paid to cultural heritage in the post-war period, because increasing urbanisation and planning ideologies like modernism were also starting to threaten traditional human-scale environments, together with the impact of growing traffic networks. The importance of preservation of cultural heritage is also connected with the tradition of preservation and repairing existing buildings and neighbourhoods as a symbol of living urbanism and urban ecology [4].

Threats caused by global warming have been recognised primarily in the biggest cities, several of which are also very vulnerable due to their coastal situation [5]. World Heritage cities, especially, have been researched and described due to their possible vulnerability risks all over the world. A special index has been given by a World Bank research study to these cities, evaluating risks from low to extreme, with a division into five different categories. These risks depend on the situation of the city and also on the socio-economic status of the residents [6]. Climate change has increasingly become a factor to consider in planning the towns and cities of the future [7]. The growing interest of this field is demonstrated, for example, by Jiang et al. [8], in a review focusing on the amount of published research dealing with climate change in urban areas from 1990 to 2016. The number of publications started to increase strongly after the early 2000s, especially after 2007. The fourth IPCC Climate Assessment Conference was arranged in 2008, and together with the United Nations Environmental Programme (UNEP), the theme of "low-carbon society" was launched. Cultural heritage has an interesting position in the climate change discussion, while the preservation of historic buildings and infrastructure also benefits the communities by saving energy and reducing carbon footprint in the building sector [9].

In the case of cultural heritage, aspects of weathering and pollution damage from acid rain and flooding, for example, have long been recognised as threats, leading to preservation action [5]. The threats of increasing temperature combined with precipitation, flooding, humidity and wind have clearly been identified to cause more damage to cultural heritage [10]. The challenge of resisting the impacts of climate change on buildings that possess cultural value is often connected with changes in social structures, such as changes in the use or maintenance of a building, which together can increase the negative impact on the condition of the object. Cultural changes can also affect the use of buildings and their maintenance. UNESCO [11] (pp. 64-65) and Haugen [12] distinguishes between direct and indirect impacts of climate change on people and the environment, speculating that indirect impacts, such as policy changes related to higher energy efficiency in protected buildings, may be of even higher relevance than direct ones.

The field of climate change impacts on cultural heritage has attracted growing interest in scientific and more general articles since the early 2000s [13,14]. Additionally, Sabbioni et al. [13], for example, previously presented some steps for recognising the threats that cultural heritage is facing, especially considering UNESCO World Heritage sites, which were brought into the wider discussion within the conventions in 2007. In the literature review of Fatorić \& Seekamp [1], the authors selected and reviewed 124 articles dealing with climate change and cultural heritage or cultural resources (a concept commonly used in the USA). The first paper that examined the role of cultural heritage 
in coastal areas and the need for sustainable strategies was published in the Journal of Cultural Heritage in 2003 [1,15]. In a study in the Netherlands, cultural heritage and environmental experts, as well as climate change experts, were interviewed about their observations with respect to culture preservation, its management, and its connection with climate change. Progressive thinking was identified in this regard, but the changing contents of management were also mentioned [16].

The extent to which those responsible for decision making and background preparations regarding cultural heritage buildings and sites, such as urban planners, are aware of the potential impact of climate change on these buildings and areas is of particular interest to the authors of this paper. In addition, from the perspective of planning, to best be able to address the threats in the future, it is important to be able to target the correct decision makers and this perceived gap of integration between planning and preservation [3]. It is the purpose here to discuss and analyse the factors involved in this aspect of the protection process. Furthermore, it is the intention to determine whether and to what extent urban planners specifically take these climate change factors into account when making shortand long-term plans for their towns and cities. Of interest to this study is how empowered urban planners feel they are in addressing these issues. One goal is also to review the level of common understanding of, and degree of preparation for climate change in the cities included in the inquiry.

The viewpoint of managing cultural heritage has been presented in previous research; for example, Philips [17] reported interviews with organisations and authorities managing cultural heritage sites in the United Kingdom, in which the main conclusion was the urgent need for updated management plans and resources for heritage sites. Sesana et al. [10] interviewed European experts in three different countries (the UK, Italy and Norway) concerning their views about the adaptation of cultural heritage to climate change and the challenges and barriers they identified. The interview results also contained suggestions for improving adaptation measures, which mostly concentrated on the management and repair of cultural heritage, but also included, e.g., cooperation with communities, stronger regulation, and development of good plans.

However, Hall et al. [18] argued that engagement with the impact of climate change on cultural heritage in planning is a challenge, due to the long-lasting time scales typical of planning processes.

The reason to explore the urban planning authorities is to widen this perspective to an area which, in principle, should consider cultural heritage as a significant element of existing environments, which are the target of urban planning actions. The input of this particular group of civil servants is important, because their statements play a major role in influencing decision makers to divert public funds towards what is regarded as necessary for preservation.

\section{Literature Review}

Climate change is defined by the United Nations as being part of the larger challenge of sustainable development [19], and therefore addressing the sustainability of cultural heritage sites also addresses climate change impacts on them. Leus \& Velhelst [20] investigated and reported on the sustainability of urban heritage sites and emphasised that sustainability can be subjective, meaning different things to different people. This is also relevant to urban planners, who are required to make choices on matters of urgency with respect to conservation, which can be based on the perceived value of certain sites or buildings compared to others in situations where public funding is limited (private funding or heritage trusts may be an option).

UNESCO and other relevant organisations, like the International Council on Monuments and Sites (ICOMOS), have already been aware of the threatening impacts of climate change on cultural heritage for several years. At a conference devoted to the topic, ICOMOS made a resolution including the recommendation that "climate change adaptation strategies for cultural heritage should be mainstreamed into the existing methodologies 
for preservation and conservation of sites, buildings, settlements, landscapes, movable objects and the living traditions and that appropriate standards and protocols should be developed for the purpose" [21]. They have also been monitoring the current changes and anticipating the future conditions dealing with heritage sites. The Intergovernmental Panel on Climate Change (IPCC) has introduced scenarios up until 2100 to demonstrate the different possible outcomes of increases in temperature. The Convention concerning the Protection of the World Cultural and Natural Heritage, which was adopted by UNESCO in 1972, already formed the basis for heritage protection in general [11] (pp. 12-15). Every country has a national legislation which adapts intergovernmental decisions considering the national and cultural situation and needs [22]. The IPCC did not specifically mention cultural heritage in association with climate change impacts until 2014 in their extensive Synthesis Report, and did so only in a limited way, referring to protecting built assets in general [23]. Although several international agreements have been ratified by European countries, there are still many administrative steps required to realise the goals of supporting and protecting cultural heritage in local-level planning. National legislation is usually drafted in coherence with the relevant international treaties, as well as with the guidance or under the control of state authorities. In local policies, the position and appreciation of cultural heritage, as well as public opinion, can have more variation, which influences the attitude and opportunities to prioritise the importance of the cultural environment in urban planning processes.

The climate impact can also be divided into direct physical impact on the cultural environment and social impact on the community and its way of living, especially when indigenous built environments are considered [11] (p. 64).

Howard [24] points out that it is often important to recognise how closely the location of cultural heritae is connected with the landscape, due to several reasons effecting the choice of suitable places. For example, hill tops and steep slopes provided suitable locations for fortresses and religious places, as well as rivers and watercourses supplying connections for trade and early industry. The understanding of the geomorphological and geological context of cultural heritage sites assists in figuring out also the present challenges and future threats by climate change.

Looking at the situation in Norway, Haugen [12] concluded that cultural heritage owners and local authorities need information and training to be able to limit the negative effects of climate change, adding that paying attention to ordinary maintenance and intensifying repairs during "normal times" may give a buffer effect for extreme conditions. She explained that knowledge of local conditions and of the risk of damage from exposure to cultural heritage buildings and sites can help in designing their protection, but that changes in the type of exposure, as is the case due to climate change, lead to unpredictable problems.

Jabareen [25] stresses how city planning has significant potential to influence adaptation and mitigation measures for dealing with climate change effects; he then analysed the contents of 20 city plans from large cities in both developed and developing countries to determine the extent to which this opportunity has been availed of. Jabareen's conclusions were that, although some cities, such as New York, London and Paris, went beyond their national governments' recommendations in terms of planning for climate change, especially with respect to adaptation, for the most part, the broader opportunities that planning could offer in this regard were not availed of. He listed problems like pandemics, street violence, poverty and economic instability as all receiving more attention than climate change.

Hasse [26], while specifically describing the development of an urban water management plan to adapt in advance to the effects of extra precipitation resulting from climate change, stressed that it took a major flood event, causing extensive damage, before it becomes a public/political issue in the part of Germany in question, and only then did it attract the interest of municipal decision makers. Hasse goes further to conclude that existing planning documents need to be developed to include the pro-active approach of "Water Sensitive Urban Design" to anticipate such needs, mentioning e.g., municipal risk monitoring as a necessary addition to aid planning. 
According to Carmichael et al. [27], climate change adaptation planning rarely makes cultural assets a primary concern, referring to the views of Adger et al. [28] that it is a mistake not to do so, as things which give meaning to people's lives, such as cultural heritage sites, need to be an essential part of adaptive planning.

The adaptation plans are considered crucial in historic environments for their future preservation. According to UNESCO [29], the existing action plans do not contain heritage as a definite priority, but concentrate on adaptation of climate change and mechanisms to respond to disasters, relevant examples of proper integration are rare. The lack of city vulnerability assessment methodologies which could integrate the impact of flooding and extreme precipitation with cultural heritage is also referred to [30].

Some essential concepts are used to describe the vulnerability of cultural heritage which is under the risk of some natural hazard. Risk is defined as the likelihood that historical building will be damaged by a hazard. Risk is affected by exposure and vulnerability, where exposure describes the physical location of heritage. For example, risks are usually detected near waterways, like by the sea, on a lakeshore or along a river. Historic buildings are often likely to suffer hazards due to their age, material, or method of construction. Cultural heritage has also been noticed to recover more slowly from natural hazards than the overall built environment [9].

The Republic of Ireland recently drew up a Climate Change Sectorial Plan for Built and Archaeological Heritage [31], where when referring specifically to the threats to cultural heritage, those listed as priorities for adaptation planning include flooding (inland and coastal), storm damage, coastal erosion, soil movement (landslip or erosion), changing burial preservation conditions, pests and mould, wildfires and maladaptation. This further identifies the need for a set of recommendations that goes beyond the scope of the National Monuments Act and the Planning and Development Act, because of the fact that much of the heritage in question remains in private ownership. The castle in Figure 1 is a good example of a major urban cultural heritage site in Ireland that is addressed in this plan.

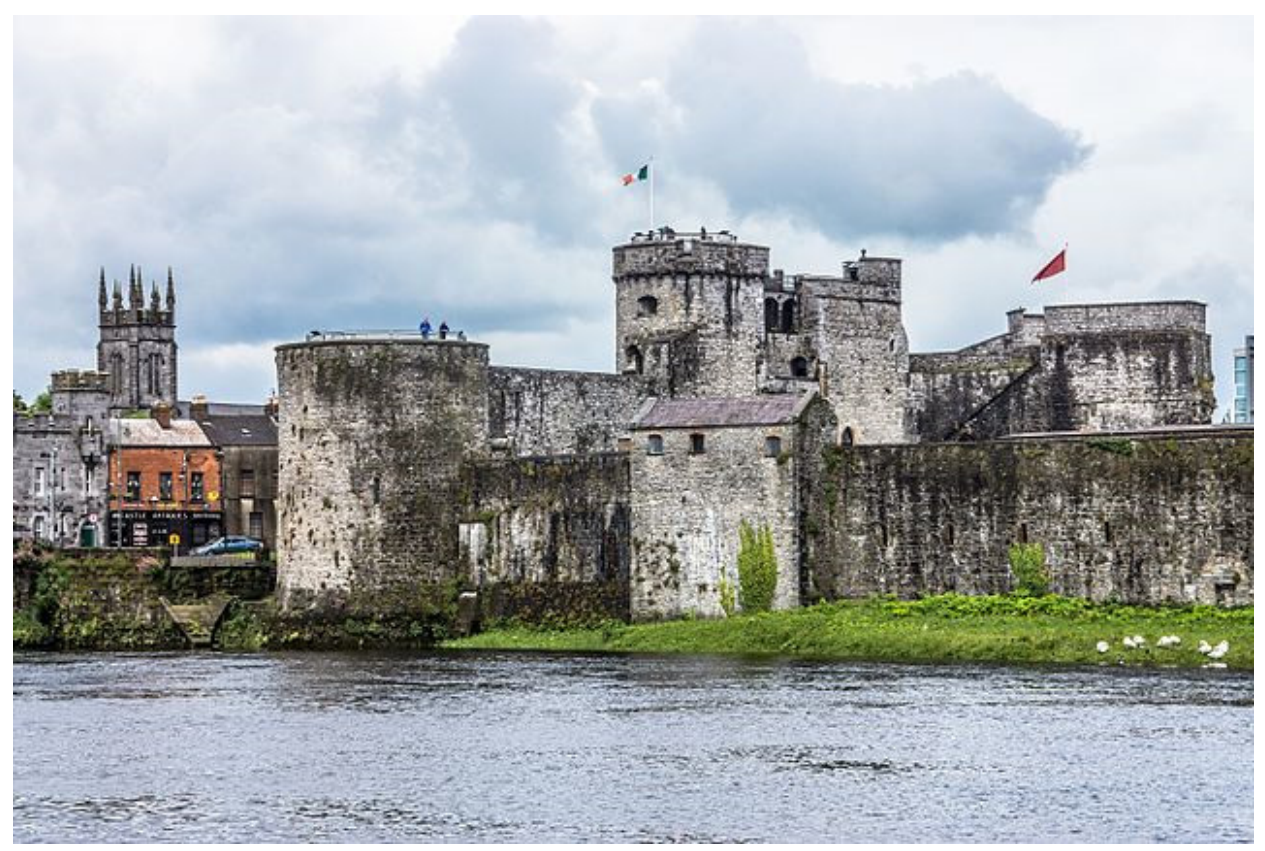

Figure 1. King John's Castle in Limerick, Ireland, built from 1200-1212, is an example of a heritage building in need for monitoring and protection from the elements. Photograph by William Murphy.

The organisation Historic Scotland has updated its climate change action plan, with the earlier version covering the period 2012-2017 [32], while the more recent programme deals with the period 2020-2025 [33]. The latter programme largely discusses the means for protecting cultural heritage, including carbon management and improving energy 
efficiency in historic buildings. The Northern Ireland Climate Change Adaptation Programme [34] covers the period 2019-2024, and provides similar viewpoints with respect to climate change adaptation and cultural heritage.

A national cultural environment strategy was published in Finland covering the period 2014-2020, and is currently undergoing a review process. The strategy was evaluated under a separate process and one finding was that the strategy was not adapted at regional and local levels in a sufficient way. Additionally, the strategy did not contain any discussion on the impacts of and adaptation to climate change [35,36].

General awareness on the topic has been increasing, and there are many ongoing research studies addressing it. Significant interest has targeted the impacts and phenomena that climate change is causing to cultural heritage including buildings, structures and sites and what kind of management plans these areas need to mitigate climate change. On the national level, countries like the Republic of Ireland, Northern Ireland and Scotland have launched well-established mitigation and adaptation strategies that consider cultural heritage, while Finland has not recognised the impact of climate change on cultural heritage in its latest strategy paper. However, it is discussed in local level urban and town planning and in decision making, but in a more limited way.

\section{Framework for an Explorative Study}

The authors proposed in their earlier work a table (Table 1) dealing with evaluation of the urgency of different climate-change-driven situations in the built environment [37] (pp. 5-6). The table is based on several research studies dealing with the most common phenomena identified in climate change impacts on cultural heritage [38-40]. This table is included here in order to compare what the authors previously proposed as the relative urgency in responding to different climate change impact factors on the one hand, to those that the interviewees in the present study most frequently referred to.

Table 1. Table demonstrating causes, results, and proposed level of urgency for acting in case studies in Southern Finland, in which the urgency rating * is classified as follows: 1-A mild or minor perceivable long-term effect (100 years or more), 3-A major perceivable long-term effect (50-100 years), 5-A mild or minor perceivable short- to mid-term effect (1-50 years), and 10-A major short- to mid-term effect (adapted from Carroll \& Aarrevaara 2018 [37]).

\begin{tabular}{|c|c|c|c|c|}
\hline $\begin{array}{c}\text { Climate Change } \\
\text { Category }\end{array}$ & Measure or Scale & Result/Effect & $\begin{array}{c}\text { Materials/Structures } \\
\text { Affected }\end{array}$ & $\begin{array}{l}\text { Proposed Urgency } \\
\text { Rating * }\end{array}$ \\
\hline \multirow{3}{*}{ Warmer climate } & \multirow{3}{*}{$\begin{array}{l}\text { Rise in degrees } \\
\mathrm{C} / \text { year }\end{array}$} & Freeze-thaw damage & $\begin{array}{l}\text { Stone } \\
\text { Brick }\end{array}$ & 3 \\
\hline & & Rust & Metal & 5 \\
\hline & & New fauna-pests & $\begin{array}{l}\text { Wood } \\
\text { Brick }\end{array}$ & 5 \\
\hline Longer growing season & Days/year & $\begin{array}{l}\text { New / increased flora, } \\
\text { algae, moss, } \\
\text { root damage }\end{array}$ & $\begin{array}{l}\text { Wood } \\
\text { Brick } \\
\text { Stone }\end{array}$ & 5 \\
\hline \multirow{4}{*}{$\begin{array}{l}\text { Increased precipitation: } \\
\text { rain or snow }\end{array}$} & $\mathrm{mm} /$ year & Humidity & $\begin{array}{c}\text { Wood } \\
\text { Brick } \\
\text { structures }\end{array}$ & 10 \\
\hline & & Increased loads (snow) & $\begin{array}{c}\text { Wood Brick } \\
\text { Roof/roof structures } \\
\text { (typically wood) }\end{array}$ & $5-10$ \\
\hline & & $\begin{array}{l}\text { Soil and material } \\
\text { degradation }\end{array}$ & Foundation base floor & 5 \\
\hline & & $\begin{array}{l}\text { Flooding (from any } \\
\text { increased } \\
\text { precipitation effect) }\end{array}$ & $\begin{array}{c}\text { Wood } \\
\text { Brick structures }\end{array}$ & 10 \\
\hline
\end{tabular}


Table 1. Cont.

\begin{tabular}{ccccc}
\hline $\begin{array}{c}\text { Climate Change } \\
\text { Category }\end{array}$ & Measure or Scale & Result/Effect & $\begin{array}{c}\text { Materials/Structures } \\
\text { Affected }\end{array}$ & $\begin{array}{c}\text { Proposed Urgency } \\
\text { Rating * }\end{array}$ \\
\hline Severe rain incidents & $\mathrm{mm} / \mathrm{h}$ & Erosion & Wood Brick stone & 5 \\
\hline Extreme winds & $\mathrm{m} / \mathrm{s}$ & $\begin{array}{c}\text { Damage to structures } \\
\text { through falling trees or } \\
\text { wind causing damage } \\
\text { to the roof }\end{array}$ & $\begin{array}{c}\text { Metal roofs Wood \& } \\
\text { brick structures }\end{array}$ & $5-10$ \\
\hline
\end{tabular}

The previous literature research indicates that in the sector of research and maintenance institutions concentrating on areas of world heritage and national heritage, the understanding of the threats caused by climate change is comprehensive [29,41].

The table above formed one set of background data compiled previously by the authors, and partly acted as a motivation for the present explorative study, which was prepared to gather information on the current situation among urban planners in cities and towns, not representing capital regions, in Finland and other European countries. The scale of urgency proposed here makes the assumption that major effects in the short or mid-term are what most need to be addressed, and therefore it can be assumed that this would have more relevance to heritage protection in present planning. Although the lowest score of 1 for urgency was defined, it was not seen as being applicable to any of the materials listed due to the prevailing accelerating rate of climate change. Table 1 was therefore prepared to serve as one aid to decision making for urban planners or other heritage protection bodies in prioritising the types of cultural heritage structures that most urgently need protection, based on their composition.

The explorative study was prepared in the format of a Webropol inquiry containing 13 different questions. The inquiry was sent in early autumn 2019 by email to a 50 urban planners or heritage authorities in Finland, Ireland, the United Kingdom (also to several recipients in Sweden, Italy and Germany, but with no answers received from these three countries) with the request to share with their colleagues and contact persons in the local city's urban planning staff. Reminders were sent two times during autumn 2019. Although the number of respondents did not turn out to be very high - there were seven responses received from Finland and three from other European countries- the inquiry still served as an exploration of a new area the authors were interested in getting in touch with.

The Finnish respondents amounted to seven in total, and the size of the cities/towns of the responses varied from less than 20,000 to more than 140,000 inhabitants.

Respondents from other countries amounted to three in total, and these were from the three small to large cities Limerick, Belfast and Glasgow, with the respondents in each case being very much involved in planning and/or cultural heritage issues. The contents of the questionnaire are given in Table 2, after which the results received are summarised and, later in this paper, discussed.

Table 2. List of the inquiry questions.

1. Background information.
Name of the respondent, contact information, organisation, position in the organisation

Open question

2. What town or municipality do your answers refer to and when was it established / how old is it?

3. Does your town/area have

nationally valuable built cultural heritage sites (buildings or areas)?

Please list them briefly.

4. The general attitude to cultural heritage in your town or area.

Open question

Answers by Likert scale 
Table 2. Cont.

5. If there is public debate in your town or area about the preservation of buildings or sites, does the issue of climate change arise?

Open question

6. Have there been any studies carried out to determine the possible effects of climate change in your town/area, e.g., flooding risks? Please mention any that Open question you are aware of.

7. List buildings or sites (from 1 to 3 different examples) in your town or area where the impact of climate change is clearly visible. Please mention in each case when the building or site was constructed and from what main materials.

8-10. For the first/second/ third building or site example mentioned above tick the observed factors caused by climate change.

11. In your opinion how should the effects of climate change be considered in areas that have valuable cultural heritage?

12. Can town planning be used to influence the preservation of buildings in terms of reducing the impact of climate change? If so, please mention in what way.

13. Please add give any additional comments on this theme that you might have.

Open question

Open question

Open question

Open question

Open question

\section{Results}

After asking for the background details of the respondents and their cities, the respondents were asked about the nationally valuable built cultural heritage sites and buildings (Question 3). In Finland, the number of cultural heritage sites depended on the history and the area of the city. Some cities have merged with the surrounding municipalities. In Ireland and the UK, the exact number of nationally valuable areas was not specified; therefore, it was simply designated as being above a certain amount. Table 3, below, gives, for the sake of comparison, numbers of relevant heritage sites in the different towns and cities involved in the study, although it should be noted that for Ireland and Britain the numbers come from protected structures or listed buildings, which is not exactly the same thing as a Finnish heritage site. Additionally, when the responses covered the number of "listed buildings", they did not specify different value categories for them.

Table 3. The respondents were asked about the existence of nationally valuable areas and buildings (environments) in their city area, and the results can be presented as follows. The population of each city is provided in the table.

\begin{tabular}{ccc}
\hline $\begin{array}{c}\text { Name of the City/Town/Year } \\
\text { of Foundation }\end{array}$ & Inhabitants (2019) & $\begin{array}{c}\text { Amount of Nationally } \\
\text { Valuable Heritage Sites }\end{array}$ \\
\hline Porvoo/1602 & 50,380 & 17 \\
\hline Jyväskylä/1837 & 142,400 & 15 \\
\hline Heinola/1839 & 18,667 & 7 \\
\hline Hyvinkää/1960 & 46,470 & 4 \\
\hline Lappeenranta/1649 & 72,634 & 12 \\
\hline Lahti/1905 & 119,823 & 14 \\
\hline Vihti/1867 * & 29,158 & 6 \\
\hline Limerick/1199 (city status) & 94,192 & $>2000 * * *$ \\
\hline Belfast/1888 (city status) & 311,512 & $>1800$ \\
\hline Glasgow $/ 1170$ & 620,000 & \\
\hline$\left.{ }^{*}\right)$ Independent municipality. $\left.{ }^{* *}\right)$ Limerick city and county. $\left({ }^{* * *}\right)$ All Northern Ireland. \\
\hline
\end{tabular}

Statements about their own perceptions of the local common attitude to cultural heritage were requested (Question 4) by giving the response options: 1 . Negative 2. Fairly negative 3. Neither negative nor positive 4. Fairly positive 5. Positive. In Finland 
the common attitude was considered by those who responded to be relatively positive on the whole, although $2 / 7$ answers chose N/A, 3/7 considered it fairly positive and $2 / 7$ considered the attitude positive. Although this is only the view of those who completed the survey of what the attitudes of the general public might be, the researchers regard these answers as quite reliable based on the familiarity with such issues obtained from their work as urban planners or involvement in cultural heritage tasks. None of the respondents considered the common attitude regarding cultural heritage as negative. In the other three cities in Britain and Ireland, the answers to this were all also fairly positive. Question 5 dealt with the connection between preservation of cultural heritage and climate change: If there is public debate in your town or area about the preservation of buildings or sites, does the issue of climate change arise? This connection was not identified by the respondents.

Previous studies dealing with climate change impacts were inquired about as follows (Question 6): Have there been any studies carried out to determine the possible effects of climate change in your town/area, e.g., flooding risks? Please mention any that you are aware of. In Finland all the respondents mentioned some kind of stormwater programme prepared for the city or the town in question. The reports can be divided into flooding risk reports and stormwater management programmes. Flooding reports are prepared at the national level, where the Finnish Environmental Institute has published a map of the significant flooding risk areas 2018-2024 covering 22 different areas where flooding can be caused by sea level or water course level rises [42]. Figure 2 is from this publication.

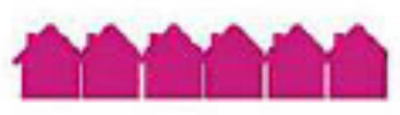

ca. 25,000 buildings

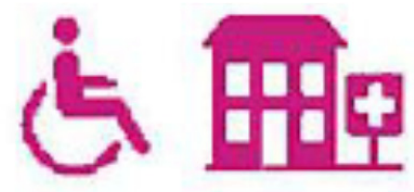

50-60 hard to evacuate buildings

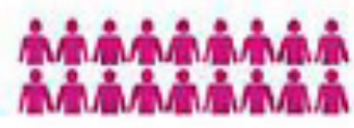

ca. 40,000 inhabitants

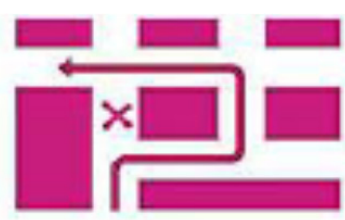

ca. $1800 \mathrm{~km}$ traffic networks ca. 400 cultural heritage sites
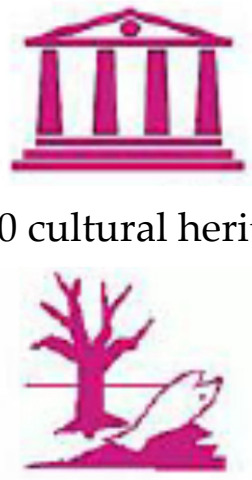

ca. 200 environment hazard sites

Figure 2. Indicators for significant flood risk areas in Finland (Based on FEI [42]).

The largest municipalities stated that in the early 2010s, stormwater programmes were prepared covering the whole city area, and these are already being updated. Several cities have also established the practice of adding a separate stormwater plan to all town plans. The responses to this question also expressed these new practices in Finland. It was noteworthy that no other actions, reports or plans were reported as being available or in preparation, considering the impact of climate change in urban areas.

Some Finnish respondents had noticed the increase of flooding, both in lakeshore and seashore situations. One respondent mentioned that in their city, situated on the shore of a large inland lake, the lowest altitude at which to build had previously been determined according to the highest flooding level once in 50 years. Recently, this requirement was changed to once in 100 years, due to the increase in flooding tendencies. Three other urban planners also mentioned the significant increase of flooding, and also surface water flow into the basements of town houses.

The following question (7) covered observations of buildings and sites where the impact of climate change was clearly visible. Detailed information about the impacting factors was asked for according to the following list (also based on Carroll \& Aarrevaara [36]). The respondents were able to present a maximum of three different examples, but the question 
was mostly responded to with only one such example being referred to (Questions 8-10). The results are summarised in Figure 3.

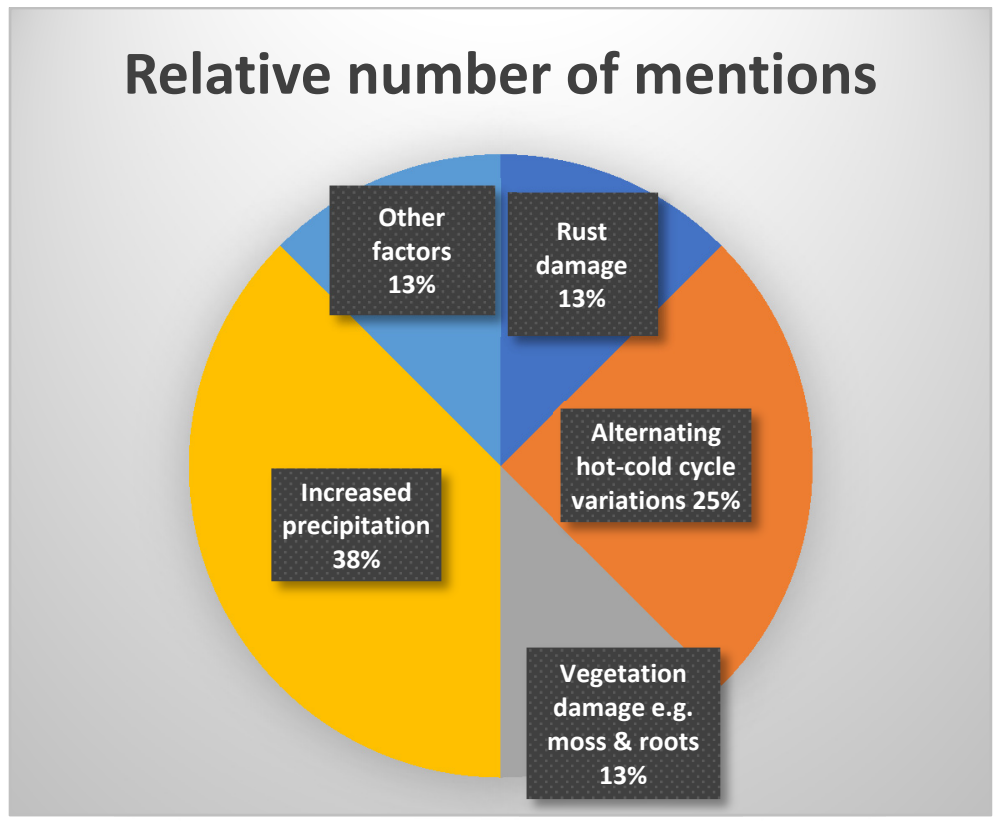

Figure 3. Observations of urban planners dealing with climate change damage factors in the cultural environment.

The respondents were asked to indicate their observations concerning the following factors:

1. Increased precipitation

2. Increased stormwater amounts

3. Increased flooding

4. Increased loads from snow

5. Alternating hot-cold cycle variations

6. Increased wind

7. Rust damage

8. Damage from new fauna species

9. Vegetation damage, e.g., from moss and roots

10. Any other factors, what are they?

\subsection{Effects of Climate Change in Areas with Valuable Cultural Heritage}

The respondents were asked their opinions about what impacts of climate change need to be considered in areas that have valuable cultural heritage (Question 11). The planners and other experts gave varied responses, but the predominant observation was connected with stormwater management and flood protection. The following excerpts contains both direct quotations and freely reported comments (translated from the Finnish where necessary).

In one response actions at governmental level were expected as a matter of urgency:

In the short term, climate adaptation measures should be identified, and action taken to protect, as far as possible, important assets from climate change. In Belfast, this particularly relates to flood risk and sea level rise.

The other factors mentioned, accounting for a total of $13 \%$ of all factors mentioned in the questionnaire, were: sea-flooding, wind and storms. Eight out of ten of the responses included a mention of stormwater management, while four out of ten mentioned flood protection specifically. Plans for flood protection and stormwater infiltration are needed and implemented (Porvoo). Stormwater management should consider better foundation 
drainage systems and water drainage especially in area development (Jyväskylä). Where the urban area is situated next to a shoreline, protective structures are needed to prevent flood damage (Lappeenranta). It was noticed that there are definitely cultural environments threatened by flooding. In these locations the situation is particularly problematic, because the relocation of buildings interrupts the pattern of linking of the site to the environment and landscape (Vihti).

For the most part, the same kinds of factors we mentioned for the Finnish cities and the Irish and British ones, except for some additional factors such as sandstone structures and failed gutters and downpipes in Glasgow and ivy growth damaging walls in Limerick. There are not many sandstone structures in Finland, and the plant ivy does not grow in the wild in its climate zone. Most Finnish traditional buildings are either made of wood, or of brick with plaster on the surface. In Figure 4, the challenge of having major cultural heritage buildings and areas in an area regularly exposed to potential water damage is highlighted.

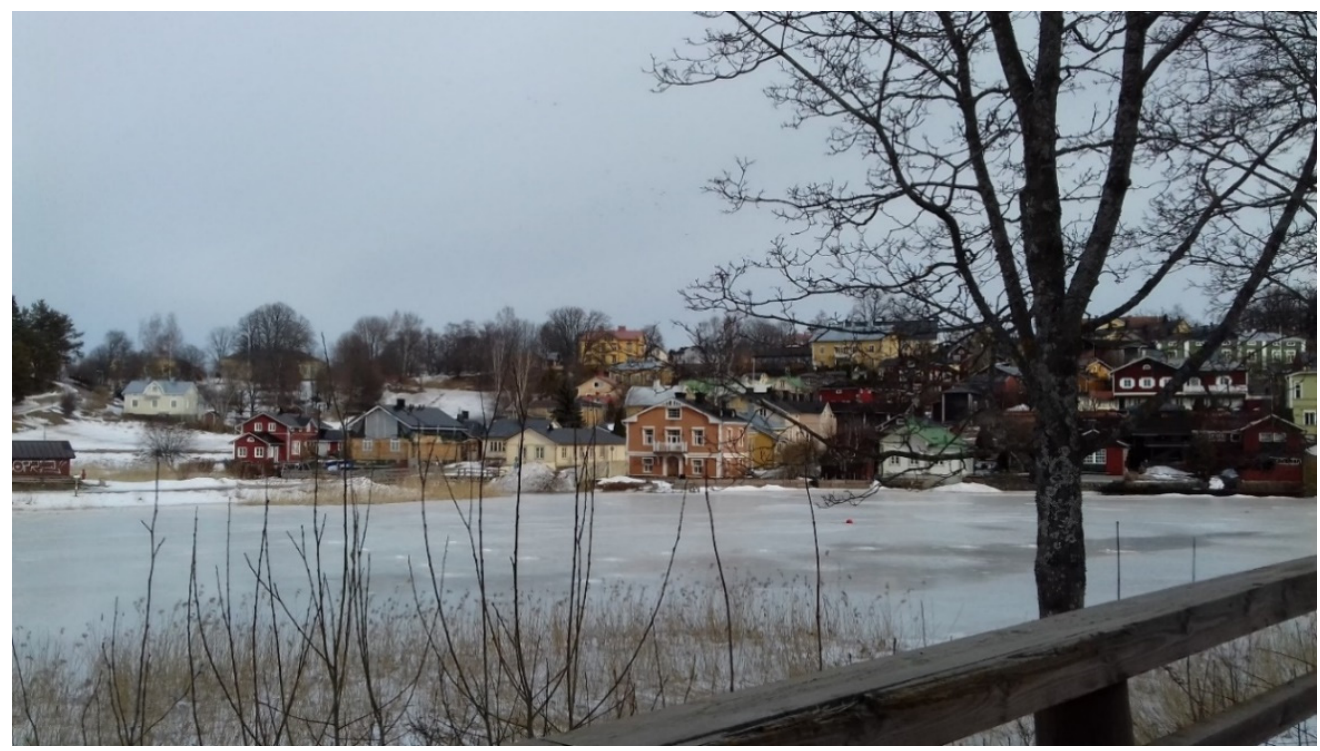

Figure 4. The Old Town part of the City of Porvoo is situated along the river and not far from the sea, where the risk of flooding is a current and relevant issue. Photograph by author Eeva Aarrevaara.

Other responses considered both stormwater management and vulnerable qualities of traditional buildings at the same time, and thereby the relationship between the building and the environment. Special care should be paid to preventing the sealing of the ground in cultural environments and to providing adequate tilting away from buildings; additionally, the air should be allowed to circulate around the building (Lahti, Vihti). It was also mentioned that carbon-neutral forms of energy should be available in urban areas to mitigate climate change impact (Porvoo).

Improvements to buildings were suggested to ensure their survival and resistance against increasing rain, wind and snow (Porvoo). It was also noticed that in the repair of buildings, the introduction of new construction standards, e.g., thermal insulation, usually causes damage to old structures and should not be demanded (Heinola). A suggestion was made to be able to replace a part of a valuable building and build a replica in its place, in a case where the building is considered significant and valuable. In general, the identity of cultural heritage and its local representatives should be considered more deeply than before (Hyvinkää). For the cultural environments it is essential that the buildings remain in use and are maintained (Vihti). Some respondents identified the need for extra funding to be made available to maintain the cultural heritage, and also in cases to raise the awareness of historical values. Extra funding could be applied in the form of grants, which might deal with treatment for dampness or for additional rethatching of roofs (since thatching does 
not last as long as before) would help (Limerick). A summary of the main cultural heritage sites in each city and the perceived threats is given in Table 4 below.

Table 4. Details of relevant cultural heritage and threats. This table introduces the target cities which the respondents represent, as well as the characteristics of the cultural heritage in each city. Additionally, the table summarises the observations of the respondents dealing with climate change impacts and damage in their city area.

\begin{tabular}{|c|c|c|c|}
\hline City, Country & Types of Cultural Heritage Sites & Climatic Factors & Damage Caused \\
\hline Porvoo, Finland & $\begin{array}{l}\text { Medieval church and town plan, } \\
\text { wooden old town }\end{array}$ & $\begin{array}{l}\text { Increased sea- and } \\
\text { river-flooding, stormwater }\end{array}$ & $\begin{array}{c}\text { Damage to the buildings } \\
\text { near water level }\end{array}$ \\
\hline Jyväskylä, Finland & $\begin{array}{c}\text { Town centre with church park and } \\
\text { university area, } \\
\text { industrial environments }\end{array}$ & Lake flooding, stormwater & Damage by stormwater \\
\hline Heinola, Finland & $\begin{array}{c}\text { Governor's residence park, old } \\
\text { teacher's college, wooden } \\
\text { town buildings }\end{array}$ & Stormwater & \\
\hline Hyvinkää, Finland & $\begin{array}{c}\text { Railway station, industrial } \\
\text { environments }\end{array}$ & Stormwater & \\
\hline Lappeenranta, Finland & $\begin{array}{l}\text { Old fortress and garrison, town hall } \\
\text { and Saimaa canal }\end{array}$ & Lake flooding, stormwater & Damage by stormwater \\
\hline Lahti, Finland & $\begin{array}{l}\text { Town hall, market square and } \\
\text { ceremony axis (church -town hall), } \\
\text { railway station, garrison }\end{array}$ & Stormwater & $\begin{array}{l}\text { Damage by stormwater, } \\
\text { building basements }\end{array}$ \\
\hline Vihti, Finland & Railway stations, village landscapes & Stormwater & \\
\hline Limerick, Ireland & $\begin{array}{l}\text { Medieval castle, town walls, } \\
\text { Georgian Quarter }\end{array}$ & $\begin{array}{l}\text { Increased wind, increased } \\
\text { precipitation }\end{array}$ & $\begin{array}{l}\text { Ivy damage to walls, } \\
\text { vegetation damage from } \\
\text { moss and weeds, } \\
\text { stormwater increase }\end{array}$ \\
\hline Glasgow, Scotland & $\begin{array}{l}\text { Cathedral and several } \\
\text { historic buildings }\end{array}$ & Increased precipitation & $\begin{array}{l}\text { Sandstone decay, failing } \\
\text { gutters and downpipes, } \\
\text { damage from moss } \\
\text { and roots }\end{array}$ \\
\hline Belfast, N. Ireland & $\begin{array}{l}\text { Industrial archeological sites, } \\
\text { vernacular sites, historic parks } \\
\text { and gardens }\end{array}$ & Flood risk & $\begin{array}{l}\text { Sea level rise (damage } \\
\text { not specified) }\end{array}$ \\
\hline
\end{tabular}

\subsection{The Opportunities of Town Planning to Preserve and Reduce the Impact of Climate Change}

The opportunities of town planning to influence the preservation of buildings in terms of reducing the impact of climate change were asked about at the end of the inquiry (Question 12). The responses received considered the different options of zoning and its contents, as well as aspects dealing with stormwater management. It was possible to identify different factors and phases in the town planning process through the responses. In general, the requirements for a sustainable planning process and its goals were described. Additionally, the importance of qualified background research and reports was mentioned. It was noticeable that communication and participation were not highlighted in the material, but only mentioned in passing. This could be interpreted as meaning that the climate change impact on cultural heritage is considered to require professional-based knowledge and understanding.

The usefulness of searching for different options and alternatives in the planning process was recognised as a positive feature. A good plan was described as being one that contains explicit regulations for preserving cultural heritage. Clear planning instructions for dealing with stormwater in urban areas were also required on a large scale. The importance of identifying the connection between a town plan and building permits was also mentioned. In the end, some uncertainties were identified, such as changes 
of legislation (in the case of Finland), and political decision-making processes and their impact on planning. Table 5 summarises the respondents' findings concerning the planning process and its contents. It can be noticed that the same observation is also shared by as many as 5 respondents connected with stormwater management solutions.

Table 5. The material from responses is grouped into different levels according to the general to detailed nature of the comments.

$\begin{array}{ll}\text { PROCESS LEVEL } & \text { the progress of climate change (Vihti, Porvoo, Belfast). Adaptation measures } \\ \text { include reducing the overall need to travel, promoting active travel, sustainable } \\ \text { design and reuse of materials. Adaptation measures include flood protection and }\end{array}$ green design (Belfast).

Separate studies and plans related to the zoning process, (e.g., stormwater management, building condition surveys) contribute to the preparation of zoning regulations as well as to the further planning and implementation of the immediate environment, supporting the preservation (Jyväskylä, Heinola, Porvoo).

BACKGROUND STUDIES, SEPARATE PROGRAMMES

\begin{tabular}{c}
\hline COMMUNICATION \\
ALTERNATIVE SOLUTIONS \\
FEATURES OF A GOOD TOWN PLAN \\
(Connected with Preservation and Climate \\
Change Adaptation)
\end{tabular}

CONNECTION TO BUILDING PERMITS
Adequate discussion and involvement (Porvoo).

Development of options and impact assessment (Porvoo). Instead of demolition it's possible to find solutions for protection together with suitable additional and supplementary construction (Porvoo).

Binding planning regulations for other environments and the building stock (Jyväskylä).

Various protection regulations play a key role (Jyväskylä).

Structural prevention of heavy rain and flood damage, flood route control, stormwater planning and planned space allocations (Lappeenranta, Lahti, Vihti, Limerick, Glasgow).

Building permit processes could be managed better when there is already a plan for applying for a permit or notification procedure (Hyvinkää).

Renewal process of the existing legislation will cause a new situation-uncertainty about the opportunities for building protection (Hyvinkää).

Political decision-making process in zoning - changes during the process always possible (Hyvinkää).

\subsection{Discussion Dealing with Themes of the Questionnaire}

The questions were also reflected on by the respondents with different connections to larger discussions in society. One city planner (from a coastal city along a river) critically evaluated the starting point of the questionnaire as follows: The influences of climate change are clearly visible — can we already say this? But sea, river and stormwater floods are nowadays more common. This statement describes the situation in which the impacts of climate change might not be clearly visible or considered as the most urgent problem in urban planning. Another respondent identified a connection between preservation and mitigation: Preserving buildings seems to be a principal means of approaching climate change mitigation in general (City planner, a coastal city in Finland).

The importance of background studies in planning processes was highlighted and several benefits were detected in a thorough preparation to the actual plan. Separate studies and plans related to the zoning process, such as stormwater management, building condition surveys etc., also contribute to the preparation of zoning regulations as well as to the further planning and implementation of the immediate environment, supporting the preservation of the built cultural environment and mitigating climate change. (City planner, a lakeshore city in Finland.) Additionally, the connection with sustainable communities, urban planning and climate change was identified in a response: On a larger scale, zoning aims to promote a sustainable community structure, which at best tackles the progress of climate change (City planner, an inland town in Finland). 


\section{Conclusions and Discussion}

Urban planning has traditionally involved accounting for present needs and anticipating future ones; in the past, this has meant integrating the potential for growth in the population and the resulting greater demands on the urban infrastructure, such as in the volume of traffic. In a time of climate change there is a new set of factors to be considered by urban planners, with corresponding new risks to be considered. Even with the ambitious scenario according to the Paris agreement of 2015, the climate will continue to change for some time, at least to a certain extent, while there is the danger that this goal of a temperature rise of only $1.5^{\circ} \mathrm{C}$ will not be reached, and there could be larger changes [43]. These uncertainties provide big challenges for urban planners in such matters as stormwater control, flood control, snow loads on buildings, and catering for high-speed winds. Cultural heritage is not usually the first priority when it comes to the safety of the population in emergency situations, where drinking water, sanitation and other basic services take priority. Nevertheless, cultural heritage buildings and sites that were constructed in a pre-climate-change period and have been preserved up until now for the common good will now need to be able to withstand additional stresses from the impacts of climate change.

This paper sets out mainly to identify how urban planners and heritage authorities perceive these challenges and how they take them into account in their work, or intend to do so in the future. The literature review provided mostly circumstantial information and findings, with these being related to international activities and trends. To address the specific question of how urban planners consider and implement climate change impacts on cultural heritage in particular, the authors carried out a small-scale survey, the results of which are provided above. As a summary, it can be stated that there is good knowledge of the general and often specific threats involved, even when these urban planners are not in a position to prioritise heritage buildings over other urban aspects in their work. However, they usually need to pay special attention to cultural heritage as a part of urban planning processes, and also to justify any actions caried out in environments containing traditional buildings. In the responses, the position of stormwater management and flooding threats was a dominant aspect of the contents. It can be stated that there is a growing need to discuss other threats that climate change is evidently causing to cultural heritage in European countries, and to facilitate for a more detailed understanding of the phenomenon among urban planners. Differences between national-level strategies were also discovered: the Republic of Ireland, Northern Ireland and Scotland have updated strategies for cultural heritage under climate change, while Finland had a more limited strategy for cultural heritage, not taking climate change into account. The authorities working in museums and other institutions responsible for cultural heritage possess specific knowledge, which should be better considered in urban planning. This need was already recognised in the introduction and literature review of this article $[3,30]$. Updated national strategies can also help in awareness raising among different professional groups.

The urban planners, and specifically employees responsible for urban heritage, who answered the survey were well aware of how well cultural heritage matters were prioritised in their cities and had realistic and constructive suggestions for what would need to be done to protect the buildings and sites in question in the future. Although limited in scope geographically (to North and West Europe) and in number of respondents, the views expressed can be regarded as being well indicative of those of urban planners as a whole. The direct quotes provided give perhaps the most valuable results of this questionnaire (free translations from the Finnish are those of the authors), offering a range of perceived needs and proposed solutions. The question about their own perceptions of attitudes is only of limited value, but it does give some indicative background information about how they reflect on the urban heritage environment in which they operate.

Summarising the findings in the literature and this exploration in the field, one can confirm the statements from the previous studies raising the awareness of the gaps arising when attempting to deal simultaneously with climate adaptation, urban planning and 
cultural heritage. The existence of different threatening phenomena is recognised as such, but the interdependence between them needs more research and interdisciplinary discussion to improve the connectivity between urban planning and climate adaptation in the perspective of cultural heritage.

Author Contributions: Conceptualization, E.A. and P.C.; methodology, E.A. and P.C.; investigation, E.A. and P.C. writing - original draft preparation, E.A. and P.C.; writing-review and editing, E.A. and P.C. Both authors have read and agreed to the published version of the manuscript.

Funding: This research received no external funding, but was enabled through the participation of the organisation in Finland, where the two authors are employed; LAB University of Applied Sciences, Faculty of Technology.

Institutional Review Board Statement: Not applicable.

Informed Consent Statement: Not applicable.

Data Availability Statement: Not applicable.

Conflicts of Interest: The authors declare no conflict of interest.

\section{References}

1. Fatorić, S.; Seekamp, E. Are cultural heritage and resources threatened by climate change? A systematic literature review. Clim. Chang. 2017, 142, 227-254. [CrossRef]

2. UNESCO, 2017 Earth Sciences; UNESCO Global Geoparks. Available online: http://www.unesco.org/new/en/natural-sciences/ environment/earth-sciences/unesco-global-geoparks/ (accessed on 30 August 2018).

3. Janssen, J.; Luiten, E.; Renes, H.; Stegmeijer, E. Heritage as sector, factor and vector: Conceptualizing the shifting relationship between heritage management and spatial planning. Eur. Plan. Stud. 2017, 25, 1654-1672. [CrossRef]

4. Calthorpe, P. Urbanism in the Age of Climate Change; Island Press: Washington, DC, USA, 2010.

5. Hunt, A.; Watkiss, P. Climate change impacts and adaptation in cities-A review of the literature. Clim. Chang. 2010, 104, 13-49. [CrossRef]

6. Bigio, A.G. Historic Cities and Climate Change. In Reconnecting the City; van Oers, R., Bandarin, F., Eds.; Wiley Blackwell: Hoboken, NJ, USA, 2015; pp. 113-128.

7. Oke, T.R.; Mills, G.; Christen, A.; Voogt, J.A. (Eds.) Urban Climates. Cambridge; Cambridge University Press: Cambridge, UK, 2017.

8. Jiang, Y.; Hou, L.; Shi, T.; Gui, Q. A Review of Urban Planning Research for Climate Change. Sustainability 2017, 9, 2224. [CrossRef]

9. Rumbach, A.; Bierbrauer, A.; Follingstad, G. Are We Protecting Our History? A Municipal-Scale Analysis of Historic Preservation, Flood Hazards, and Planning. J. Plan. Educ. Res. 2020, 1-14. [CrossRef]

10. Sesana, E.; Gagnon, A.S.; Bertolin, C.; Hughes, J. Adapting Cultural Heritage to Climate Change Risks: Perspectives of Cultural Heritage Experts in Europe. Geosciences 2018, 8, 305. [CrossRef]

11. UNESCO. Case Studies on Climate Change and World Heritage; UNESCO World Heritage Center: Paris, France, 2007.

12. Haugen, A. Preparations for climate change's influences on cultural heritage. Int. J. Clim. Chang. Strateg. Manag. 2011, 3, $386-401$. [CrossRef]

13. Sabbioni, C.; Cassar, M.; Brimblecombe, P.; Lefevre, R.A. Vulnerability of Cultural Heritage to Climate Change. Council of Europe. 2008. Available online: https://www.coe.int/t/dg4/majorhazards/ressources/Apcat2008/2008_44_culturalHeritage_EN.pdf (accessed on 24 August 2018).

14. Bertollin, C. Preservation of Cultural Heritage and Resources Threatened by Climate Change. Geosciences 2018, 9, 250. [CrossRef]

15. Vallega, A. The coastal cultural heritage facing coastal management. J. Cult. Herit. 2003, 4, 5-24. [CrossRef]

16. Fatorić, S.; Egberts, L. Realising the potential of cultural heritae to achieve climate change actions in the Netherlands. J. Environ. Manag. 2020, 274, 1-9. [CrossRef] [PubMed]

17. Phillips, H. Adaptation to climate change at UK World Heritage sites: Progress and challenges. Hist. Environ. Policy Pract. 2014, 5, 288-299. [CrossRef]

18. Hall, M.; Baird, T.; James, M.; Ram, Y. Climate change and cultural heritage: Conservation and heritage tourism in the Anthropocene. J. Herit. Tour. 2016, 11, 10-24. [CrossRef]

19. UN DESA (United Nations Department of Economic and Social Affairs, Division for Sustainable Development). Climate Change Mitigation and Sustainable Development. 2007. Available online: https://sustainabledevelopment.un.org/content/documents/ 1489mitigation_paper.pdf (accessed on 2 February 2020).

20. Leus, M.; Verhelst, W. Sustainability Assessment of Urban Heritage Sites. Buildings 2018, 8, 107. [CrossRef]

21. ICOMOS (International Council on Monuments and Sites) Resolution at the International Workshop on Impact of Climate Change on Cultural Heritage New Delhi. 2007. Available online: https://www.icomos.org/climatechange/pdf/New_Delhi_Resolution_ EN.pdf (accessed on 2 February 2020). 
22. UNESCO. List of National Cultural Heritage Laws. 2021. Available online: https://en.unesco.org/cultnatlaws/list (accessed on 17 May 2021).

23. IPCC. Climate Change 2014: Synthesis Report. Contribution of Working Groups I, II and III to the Fifth Assessment Report of the Intergovernmental Panel on Climate Change; Core Writing Team, Pachauri, R.K., Meyer, L.A., Eds.; IPCC: Geneva, Switzerland, 2021; p. 151.

24. Howard, A.J. Managing global heritage in the face of future climate change: The importance of understanding geological and geomorphological processes and hazards. Int. J. Herit. Stud. 2013, 19, 632-658. [CrossRef]

25. Jabareen, Y. City planning deficiencies \& climate change-The situation in developed and developing cities. Geoforum 2015, 63, 40.

26. Hasse, J. From vision to action: Roadmapping as a strategic method and tool to implement climate change adaptation-the example of the roadmap 'water sensitive urban design 2020'. Water Sci. Technol. 2016, 73, 2251-2259. [CrossRef]

27. Carmichael, B.; Wilson, G.; Namarnjilk, I.; Daly, C. Testing the scoping phase of a bottom-up planning guide designed to support Australian Indigenous rangers manage the impacts of climate change on cultural heritage sites. Local Environ. 2017, 22, 1197-1216. [CrossRef]

28. Adger, W.N.; Barnett, J.; Chapin, F.S., III; Ellemor, F. This must be the place: Underrepresentation of identity and meaning in climate change decision making. Glob. Environ. Politics 2011, 11, 1-25. [CrossRef]

29. UNESCO. What is Meant by Cultural Heritage? 2020. Available online: http://www.unesco.org/new/en/culture/themes/illicittrafficking-of-cultural-property / unesco-database-of-national-cultural-heritage-laws/frequently-asked-questions / definitionof-the-cultural-heritage/ (accessed on 15 February 2021).

30. Gandini, A.; Garmendia, L.; Prieto, I.; Alvarez, I.; San-José, J. A holistic and multi-stakeholder methodology for vulnerability assessment of cities to flooding and extreme precipitation events. Sustain. Cities Soc. 2020, 63, 102437. [CrossRef]

31. Government of Ireland, Department of Culture, Heritage and the Gaeltacht. Built and Archaeological Heritage, Climate Change Sectoral Adaptation Plan. 2019. Available online: https://www.chg.gov.ie/heritage/climate-change/the-built-andarchaeological-heritage-climate-change-sectoral-adaptation-plan/ (accessed on 26 November 2020).

32. A Climate Change Action Plan for Historic Scotland 2012-2017. Available online: https://www.historicenvironment.scot/media/ 2611/ climate-change-plan-2012.pdf (accessed on 17 May 2021).

33. Historic Environment Scotland. Climate Action Plan 2020-25. 2020. Available online: https://www.historicenvironment.scot/archivesand-research/publications / publication/?publicationId=94dd22c9-5d32-4e91-9a46-ab6600b6c1dd (accessed on 19 May 2021).

34. Northern Ireland Climate Change Adaptation Programme 2019-2024. Climate Change Unit, Environmental Policy Division, Environment, Marine and Fisheries Group, Department of Agriculture, Environment and Rural Affairs (DAERA). Available online: https: / / www.daera-ni.gov.uk/publications/northern-ireland-climate-change-adaptation-programme-2019-2024 (accessed on 19 May 2021).

35. Kulttuuriympäristöstrategia 2014-2020. Opetus- Ja Kulttuuriministeriö, Ympäristöministeriö. 2014. Available online: https:/ / helda.helsinki.fi/bitstream/handle/10138/43197/Kulttuuriymp\%C3\%A4rist\%C3\%B6strategia_2014.pdf?sequence=1 (accessed on 17 May 2021). (In Finnish).

36. Kulttuuriympäristöstrategian (2014-2020) Arviointi. Valtioneuvoston Julkaisuja 2021:3. Available online: https://julkaisut. valtioneuvosto.fi/bitstream/handle/10024/162680/VN_2021_3.pdf?sequence=1\&isAllowed=y (accessed on 17 May 2021). (In Finnish).

37. Carroll, P.; Aarrevaara, E. Review of Potential Risk Factors of Cultural Heritage Sites and Initial Modelling for adaptation to Climate Change. Geosciences 2018, 8, 322. [CrossRef]

38. Brimblecombe, P. Refining climate change threats to heritage. J. Inst. Conserv. 2014, 37, 85-93. [CrossRef]

39. Forino, G.; MacKee, J.; von Meding, J. A proposed assessment index for climate change-related risk for cultural heritage protection in Newcastle (Australia). Inter. J. Disaster Risk Reduct. 2016, 19, 235-248. [CrossRef]

40. Kaslegard, A. Climate Change and Cultural Heritage in the Nordic Countries; TemaNord 2010:599; Nordic Council of Ministers: Copenhagen, Denmark, 2011; pp. 9-18.

41. European Commission. Safeguarding cultural heritage from natural and man-made disasters. In A Comparative Analysis of Risk Management in the EU; EU Publications: Luxembourg, 2018; pp. 54-57.

42. Finnish Environmental Institute (FEI). Suomen Tulvariskien Ennakoidaan Kasvavan Tulevaisuudessa. 2020. Available online: https:/ / www.syke.fi/fi-FI/Ajankohtaista/Suomen_tulvariskien_ennakoidaan_kasvavan (accessed on 30 September 2019).

43. UNEP Emissions Gap Report 2019 Global Progress Report on Climate Action. 2019. Available online: https://www. unenvironment.org/interactive/emissions-gap-report/2019/ (accessed on 30 August 2018). 